\author{
Aneta Kaftańska \\ University of Bialystok \\ anetakaftanska@interia.pl \\ Natalia Rogowska \\ University of Bialystok \\ nataliaracewicz@gmail.com
}

\title{
Shape of Mediation Procedures for the Amendment of the Civil Code of Conduct - an Attempt to Assess Some Changes from the Perspective of Judges
}

\begin{abstract}
For the first time since mediation was introduced in the Code of Civil Procedure in 2005, the Polish legislator recognized the need to develop comprehensive changes in the procedure. Since the $1 \mathrm{Ja}-$ nuary 2016 amendment, judges are expected to take a more important part in encouraging mediation. These amendments assume that citizens will be more willing to participate in mediation when they are aware of what it is and the procedure of mediation is better known. The amendments saw mediation as a remedy to lighten the work of the courts. This article attempts to analyze the changes from the judges' point of view and their experience with mediation. In particular, the article identifies barriers in directing cases to mediation recognized by judges on the basis of the law before the amendments. These considerations also shall indicate whether the current shape of the procedures, evaluated by the judges, has a chance to shorten disputes, improve court proceedings and reduce the cost of lawsuits.
\end{abstract}

Keywords: mediation, amendment, judges' duty, court

\section{Introduction}

One of the basic and universal needs of every human being is a desire to live in harmony with other people. Therefore, should a conflict appear, a person naturally tends to attempt to resolve it. The statistics from the Ministry of Justice ${ }^{1}$ indicate that this is when Poles like to take things to court. However, is this really the most effective

1 Data available at the Ministry of Justice's webpage "Report on the activities of general jurisdiction courts in 2010-2014 (February 2015)". The document has been issued by the Department of Stra- 
and most advantageous solution from the point of view of opposing parties? Is the only way to resolve a conflict really a court proceeding?

In an era when Polish courts are burdened with a significant workload, these questions are asked more and more often. This has prompted lively discussion about the value of conciliation and actions undertaken by enthusiasts of alternative dispute resolution procedures to promote this method ${ }^{2}$.

\section{The intentions of the legislator and introduced changes}

Currently, mediation procedure is at an extraordinary point in its history. On January 1 2016, an act amending ${ }^{3}$ the Code of Civil Procedure ${ }^{4}$ has been introduced, bringing changes to (amongst others) mediation procedures. For the first time since mediation was introduced into the Polish Civil Procedure Code in 2005 ${ }^{5}$, the Parliament enacted major changes to mediation procedures.

In supporting the draft amendments, the Ministry of Justice ${ }^{6}$ said that their main aim was to shorten, streamline, and reduce the cost of litigation, both for the citizens and the state. The Parliamentary report said that more information on the mediation procedures at the pre-judicial (attorneys) and judicial (judges) stage is the best way to propagate this method. Understanding the term "mediation" and the procedure of its application may be a chance to increase willingness to participate in it. As a result, this procedure might become the remedy to the overwhelming workload at courts.

tegy and European Funds, and is available on the Statistic Information of the Justice System, www. isws.ms.gov.pl (29.01.2016).

2 The examples for rising interest in mediation are i.e.: the project "Centre of Arbitration and Mediation - a pilot project initiated in 2014 by the Ministry of Economy", which established six regional centres of Arbitration and Mediation (Centre of Arbitration and Mediation - CAM) in Bialystok, Katowice, Krakow, Lublin, Poznan and Warsaw. Since 2011, every year, Poland celebrates the International Day of Mediation and the so-called "weeks of mediation". In addition, it's more and more often that the central theme of law conferences is mediation, among others: "Economic mediation in business and administration" (the conference was held on 8.06.2015 in Bialystok, organized by the Podlasie Centre of Arbitration and Mediation); "Polish Congress of Litigation \& Dispute Resolution, Mediation and Arbitration" organized annually in Warsaw by the Allerhand Institute; "Mediation as a new category of legal activity" - conference organized by the Mediation Centre cooperating with the Lewiatan Confederation and the Forum of Civil Development in Warsaw (held on 28.10.2015).

3 Act of 09.10.2015 amending certain acts in relation to the promotion of amicable dispute resolution (OJ 2015 pos. 1595).

4 Act of 11.17.1964 on the Code of Civil Procedure (Journal of Laws 2014, item. 1635, as amended).

5 Act of 28.07.2005 amending the Code of Civil Procedure and some additional acts (Journal of Laws 2005, No. 172, item. 1438); provisions of this Act were applied on 10.12.2005.

6 Justification of the Project of the Act for amending the Acts - Code of Civil Procedure and some other acts in relation to the promotion of amicable dispute resolution, published on the website of the Government Legislation Centre, www.legislacja.rcl.gov.pl (2.04.2016). 
On the other hand, when reading the novelization, one finds it supports the view that from 1 January 2016 the legislator makes the judges fully responsible for persuading the conflicted parties to participate in mediation at the judicial stage. And it is the judges, who - as the authorities in the field of justice administration - have now the ability to effectively increase the number of mediations. This opinion seems to be particularly supported by the new wording of Article. 10 of the Code of Civil Procedure. So far, in cases where a settlement was acceptable the court should attempt to resolve them amicably. Currently, this provision simply indicates that in cases where a settlement is acceptable, the court is to seek an amicable settlement, particularly by urging the parties to mediation. The rest of the changes relating to the judge's duties include:

1. Enforcing the obligation of parties to inform in the lawsuit if an amicable settlement of the dispute has been attempted - art. $187 \S 1$ point 3 Code of Civil Procedure;

2. Inform about and urge the parties to attempt mediation, in particular by:

- the ability to order the parties to participate in the informational meeting or to order the parties to participate in an in camera meeting - art. $183^{8} \$ 4$ and 5 Code of Civil Procedure,

- the possibility of turning to mediation at any stage of the proceeding and even more than once in the same proceeding;

3. Considering the representative's commitment to the actions allowing to amicably resolve the dispute, when determining the remuneration for the representative; ${ }^{7}$

4. Allowing for studying the circumstances which would allow to burden the party, which openly and unreasonably refused to submit to mediation, with part of the costs incurred as a result of strongly reprehensible and disloyal conduct against the court or the opposing party- Art. 103, Art. $183^{8} \$ 6$ Code of Civil Procedure.

During the new phase, the main assumptions of the legislature - to share knowledge about mediation and other amicable methods possibilities - will be implemented.

\section{Changes in the civil procedure from the perspective of judges}

These changes will apply from the beginning of this year; therefore, it is too early to assess applying them in practice. Referring to the changes, which put the emphasis on the work of a judge and his/her involvement in promoting mediation, it's worth

7 See, for example $\$ 15$ paragraph. 3 sect. art 1 of the Ordination of the Minister of Justice from 22 October 2015 on fees for legal advisers, OJ from 2015, item. 1804. 
taking notice of their previous experience in this field, and ask how the people in question - the judges - see the amendment. The starting point for these considerations was the discussion between representatives of different legal professions, including the judicial community, on the first Podlaski seminar devoted to Alternative Dispute Resolution methods ${ }^{8}$. In addition, the authors have conducted interviews with judges in Białystok ${ }^{9}$.

Polish judges are divided in their opinion of mediation. Some support its increased use while others consider it doomed to failure ${ }^{10}$. This position is usually backed by the Polish mentality, which due to its particular character and the Polish history of the XX century is not ready for the amicable settlement of disputes. Besides, there are also judges who believe only in their own qualifications and consider mediation a waste of time ${ }^{11}$.

In turn, the judges who advocate for mediation argue that the changes made by the legislator on 1 January 2016 were required ${ }^{12}$. It should be noted, however, that even among judges who support mediation, there are voices of criticism, relating primarily to the new shape of the institution of mediation and the additional responsibilities the amendment will push on the judges. What is considered to be the actual advantage of the introduced changes is the very interest of the Polish legislator in the mediation process. According to the judges, the provisions of law on mediation in civil procedure have not been updated in a significantly great time, and require refinement and a push in the right direction. The judicial community has pointed out the above points before ${ }^{13}$. The legislator, by introducing the discussed changes, essen-

The first Seminar on Alternative Dispute Resolution Methods in Podlasie, titled "Mediation in civil and economic matters in Europe - challenges and prospects", 13 November 2015 at the Faculty of Law, University of Bialystok.

9 The aim of the study was to investigate the opinion of the judicial community about changes in mediation in the Polish Code of Civil Procedure from 1 January 2016. The main question of our study was: How the changes in civil procedure will impact on the number of mediations in Poland. The data selection was random. The studies included 10 judges within the jurisdiction of the appeal Bialystok - District Court in Bialystok, Ostroleka and Bielsko Podlaski. The scope of studies narrowed to the area of Bialystok appeal because of the domicile of the authors. The research was qualitative. They were carried out using in-depth interview. The interviews were conducted in the period from 13 November to the end of December 2015.

10 During the conference, representatives of the judiciary pointed out the insufficiency of trust to the mediators, mainly due to the lack of law criteria for the mediator's competence.

11 As said one of the interviewed judges.

12 A. Czerwinski, Mediacja z punktu widzenia sędziego, published on the website of Arbitration and Mediation Centre (Centrum Arbitrażu i Mediacji), www.caim.gov.pl/index.php/pl (1.02.2016).

13 Already in 2008 the Supreme Court Judge Teresa Romer noted that mediation "(...) even though the relevant regulations for the procedure are in place, it is still not applied enough in the practice of resolving emerging conflicts." As the reason for this she saw "the lack of sufficient knowledge about the essence of mediation and its benefits" see T. Romer, Słowo o książce, (in:) M. Bobrowicz, Mediacja jestem za, Warszawa 2008, p. 14. This particularly addressed the lack of information on 
tially implemented the majority of suggestions, including giving the judges an important role in promoting mediation in the early stage of the court proceedings.

The inspiration for wording the regulations this way are the experiences from other countries where the procedure is used more often because it is encouraged by the judges by extensively informing the conflicted parties (including the US, Canada, UK, Germany $)^{14}$. The judges also cite as important that "the duration of the mediation is not included in the duration of the court proceedings ${ }^{15 "}$ (Art. $183^{10} \S 1$ Code of Civil Procedure). This provision is of paramount importance for the judge's practice $^{16}$. The previous regulation - as the interviewed judges stressed - had proven to be a significant obstacle in passing cases to mediation. The judges did not want to expose themselves to complaints about the excessive length of pending cases and the correlated disciplinary consequences and subsequently did not turn to mediation or did so in a limited way. The change will thus eliminate the possibility of judge's liability in connection to the long duration of the mediation procedure. This is particularly important when it comes to cases that are not to be resolved by settlement and return to the court. There is some risk that, after an unsuccessful mediation, the conflict between the parties will escalate, the facts of the case can present additional complications, which can hinder and extend the time to resolve the issue before the court.

Some judges optimistically assume that the institution of mediation (provided it will be used frequently enough) might contribute to even eliminate the excessive length of judicial proceedings. All the interviewed judges said it was necessary for a mediator to deal with the cases, which guarantees the due conduct of the procedure. They pointed out that often during the deciding factor in not encouraging mediation is lack of confidence in the available mediators, and the fear that, if mediation fails, the conflict between the parties will escalate, resulting in further complications and lengthening of the lawsuit. Thus, one might conclude that currently the main obstacle to fully utilizing the advantages of mediation is the difficulty in communication between judges and mediators, who in most cases also are lawyers. This also was the conclusion of the discussion held at the aforementioned first Seminar in Podlasie.

the essential benefits of mediation, namely: its speed and cost when compared to a traditional process, but also information about the chance for the parties to restore and maintain undistorted, proper communication and relationships, both during the course of the mediation procedure as in the future. See A. Kalisz, A. Zienkiewicz, Mediacja sądowa i pozasądowa zarysy wykładu, Warszawa 2013, p. 43.

14 J. Sauter-Kunas, Mediacja - nowe otwarcie, "Na wokandzie" 2016, No. 1(27), p. 8; the same article was published on the website of TVN 24 BiS, www. tvn24bis.pl (23.04.2015).

15 A. Czerwinski, Mediacja z punktu widzenia sędziego, published on the website of Arbitration and Mediation Centre (Centrum Arbitrażu i Mediacji), www.caim.gov.pl/index.php/pl (01.02.2016).

16 A. Biłgorajski expressed a similar view in an article entitled: Instytucja mediacji w kontekście konstytucyjnego prawa jednostki do rozpatrzenia jej sprawy bez nieuzasadnionej zwłoki, „ADR” 2014, No. 1(25). 
The judges said they would be more likely to refer a case for mediation if they knew the mediator personally.

The judges are concerned not only about the mediator's skills, but also about their so-called specialization. It is important because in this way the judge which sends the issue to an experienced and educated mediator, has a better guarantee of success of the procedure. It requires a different set of skills for business negotiations, where the parties to the conflict are mostly large enterprises and the dispute usually is about money versus family matters, where the parties are family members, and often the conflict grows over the years, feeding on emotions and feelings. This practice could allow to increase the trust of judges to mediation, furthermore increasing the number of cases referred to mediation. Meanwhile, the legislation lacks specific requirements for the mediator candidate. Despite the changes in the field of mediation, the regulations of the profession of a mediator have not been clarified, which causes all the requirements to be quite vague ${ }^{17}$. The legislation process does not mention any specific education in the field required for mediators except in family mediation ${ }^{18}$. Therefore, the judges' reservations about mediators' qualifications may be justified. Despite the changes, the current alternations are still not precise enough to guarantee a duly conducted mediation. However, according to the authors of this paper, the improvement of communication does not need to stem from limiting the access to the profession. Sometimes appropriate personality traits are enough to carry out a good mediation, and the character might be more important than knowledge. Therefore, a good solution to the "lack of faith in mediators" may be the implementation of informal habits. It is worth to consider the personal presentation of a mediator to a judge outside the courtroom. This would allow the judge, who knows the nature of the case, to be able to choose a mediator, whom they met personally and whom they believe to have the best predisposition to conduct the case.

The frequency of directing cases to mediation also depends, as it seems, on the size of the court. In small units, where the judges have less workload and adjudication is working properly, they likely would not be interested in directing the case to mediation. The situation is different in high courts, where the waiting time for a hearing is up to a couple of months. The amendment extended the period for initiating mediation to 3 months, so we can theoretically assume that in bigger courts the judges

17 A mediator in civil matters may be any natural person with full legal capacity and exercising full public rights, except for the judge who is not retired. The so called "regular mediator" is listed on the list maintained by the President of the District Court. They have to meet additional requirements, i.e.: no conviction for an offense, are at least 26 years of age, know the Polish language, have knowledge and skills in mediation and provide documents that convincingly attest professional preparation.

18 Art. $436 \$ 4$ Code of Civil Procedure states that if the parties have not agreed on a mediator, the court directs them to a permanent mediator having theoretical knowledge, with a degree in psychology, pedagogy, sociology or law and practical skills in the field of mediation in family matters. 
will have the possibility to use the waiting time in order to attempt conciliation (by organizing information meetings and in camera meetings in order to push the case to mediation. It is possible, after all, that the parties will reach an agreement before the time of the hearing comes round.

On the other hand, in large units there is the risk that the judges, usually managing the overloaded office, will have the organizational capability and time to conduct in camera meetings with the parties, even if the cases in the office have distant hearing dates. The above incites to consider a couple of inconsistencies in the new procedure. As mentioned at the beginning, the reason for introducing the amendment was to minimize the judges' workload by reducing the number of cases in the courts, however, in reality it places new obligations on the judges. Although the legislator has provided the possibility of the informational briefings to be organized by others (clerks, assistants to judges, permanent mediators), the law contains no detailed regulations on their course. It is therefore difficult to assess whether this solution will in any way serve to speed up the work of judges, or perhaps will prove to be counterproductive.

\section{Summary}

In summary, it can be said that most judges received the new legislation on the mediation procedure enthusiastically. A large part of the environment sees huge potential in mediation and a chance to deal with the problems of the justice system. The proposed specific changes, although partially criticized, have been received with a credit of trust on the part of the representatives of the environment. The judges are wary of the additional responsibilities which have been imposed on them. Although there is a large group of mediation enthusiasts among the judges' ranks, actively engaging in its propagation, it is a concern, however, that the responsibility for the effectiveness of mediation has been placed on them. Almost certainly the practice itself will best verify the intention of the legislator and time will tell if the effort spent on information briefings will bring long-term benefits in the form of more conducted mediations, decreasing the workload of judges and increasing the number of cases closed with a settlement. Obviously, the activity of judges will translate into increased mediation awareness among the general public. However, it seems that this might not be enough to guarantee the success of mediation in Poland. In addition to the obligation to inform the parties to the dispute after they bring their claims to the court, it is important to undertake parallel educational activities for people who have not yet stood before a court of law. This can be accomplished by social campaigns publicized by the mass media. The introduction of school-suitable content, dealing with broadly understood peace, dialogue and amicable conflict resolution methods should also be considered. Such a double-track activity will quickly yield results. A party educated 
in amicable dispute resolution, will be ready to consciously undertake the mediation route, before the judge will attempt to persuade them in a court. Then the informative role of the courts and judges will not be a factor ultimately determining the level of awareness of parties in need of mediation.

Consequently, the judge will no longer bear sole responsibility for each attempt to undertake a mediation procedure. Therefore, according to the authors, the discussed changes deserve approval, provided always that they were only the beginning of the improvement in the institution.

In the future, attention of the legislators should attract a matter of competence of the mediators, their substantive preparation for mediation in a certain field, and perhaps the introduction of some form of specialization. Then, the desire of the legislator to educate the parties about the arbitration procedure should be also assessed positively. However, by encumbering the judges almost entirely in this field, the legislature has forgotten that one of the goals of mediation was to relieve courts from too many cases. Therefore, it clearly shows that in the future, the task of the legislature should be to rectify this situation and improve legislation in this area.

Among all changes, the most positive is the obligation for parties to inform in legal motions about any attempts of solving the dispute by an amicable method. This is the moment when parties will be able to initiate a mediation, even if they did not consider it previously.

This is the moment when parties will be able to initiate a mediation, even if they did not consider it previously. In this way, the legislator not only educates the parties by showing the possibility of mediation, but first and foremost increases the responsibility of the professional attorney who usually is the constructor of a lawsuit. Thereby, this change is especially good, because it can motivate parties to mediate before the case goes to the judge's desk.

\section{BIBLIOGRAPHY}

Bobrowicz M., Mediacja jestem za, Warszawa 2008.

Biłgorajski A., Instytucja mediacji w kontekście konstytucyjnego prawa jednostki do rozpatrzenia jej sprawy bez nieuzasadnionej zwłoki, „ADR” 2016, No. 1(25).

Czerwiński A., Mediacja z punktu widzenia sędziego, www.caim.gov.pl/index.php/pl (1.02.2016).

Kalisz A., Zienkiewicz A., Mediacja sądowa i pozasądowa. Zarys wykładu, Warszawa 2013.

Sauter-Kunach J., Mediacja - nowe otwarcie, „Na wokandzie” 2016, No. 1(27). 